\title{
EKSOTIKA INSKRIPSI ARAB PADA KERIS TANGGUH KAMARDIKAN
}

\author{
Abdul Jawat Nur ${ }^{1,2}$ \\ ${ }^{1}$ Program Studi Sastra Arab Fakultas Ilmu Budaya \\ Universitas Gadjah Mada Yogyakarta \\ ${ }^{2}$ Email: jawatnurugm.ac.id
}

\begin{abstract}
This study discusses the exotic Arabic inscriptions on kamardikan kris based on sociopragmatic studies. This research is interesting to do because not all kamardikan kris found Arabic inscriptions. The existence of Arabic inscriptions on the kamardikan kris is interesting to study from the type of Arabic script and also the intention of the owners to collect the kris. The method used in this study is the method of providing data, the method of analyzing data, and the method of presenting the results of data analysis. Based on an analysis of the types of Arabic script on the kamardikan keris it is concluded that Arabic writings on the kamardikan kris use one type of writing, namely naskhi writing and diwāni writing and some use a combination of several types of writing, namely (a) naskhi and diwāni writing, (b) Naskhī, Tugrā, and Ś uluśi writing, (c) Naskhì, Tugrä, and Raihan̄i writing, (d) naskhì and Diwani JaIi writing, and (e) writing the tattoo. Based on sociopragmatic studies, the Arabic inscriptions on the kamardikan kris have (a) aesthetic, (b) symbolic, (c) safety, and (d) success functions.
\end{abstract}

Key words: kamardikan kris, Arabic inscriptions, sociopragmatics

$$
\begin{aligned}
& \text { ملخص } \\
& \text { يناقش هذا البحث النقش العربي العجيب فن الكيريس (السيف الجاوي التقليدي) كامارديكان مبنيا على دراسة }
\end{aligned}
$$

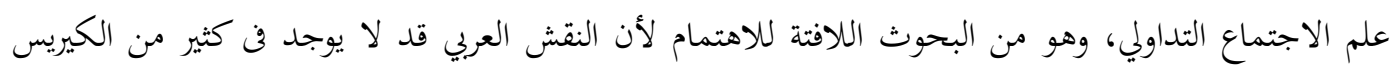

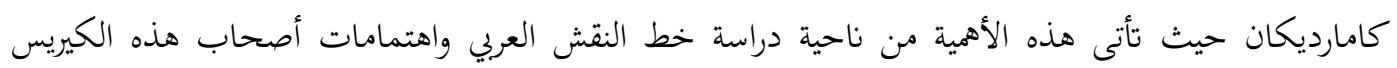

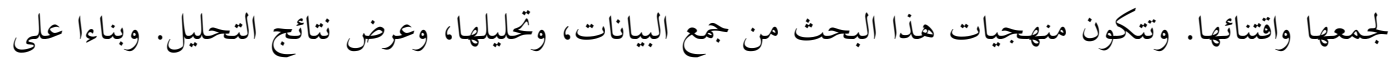

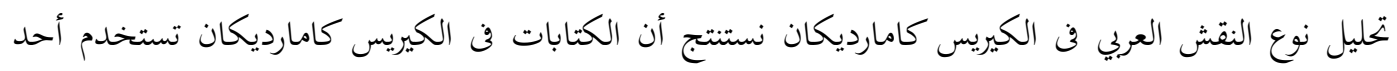

$$
\begin{aligned}
& \text { أنواع هذه الخطوط، هي: خط النسخ، وخط الديواني، وبعض تراكيب الخطوط مثل خط النسخ مع الديوانى، }
\end{aligned}
$$

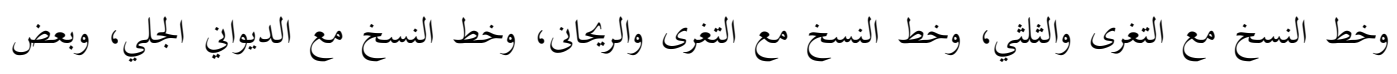

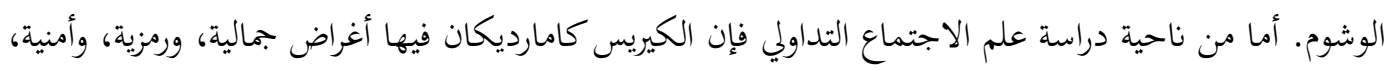

$$
\begin{aligned}
& \text { ونجاح. } \\
& \text { الكلمات المفتاحية: الكيريس كامارديكان، النقوش العربية، علم الاجتماع التداولي. }
\end{aligned}
$$

\section{A. Pendahuluan}

Peristiwa pengembalian keris Pangeran Diponegoro oleh pemerintah Belanda ke Indonesia merupakan peristiwa bersejarah yang penting (https://tirto.id/eDRW, Selasa, 10/3/2020). Menurut Presiden Jokowi (https://tirto.id/eDRW), pengembalian keris Pangeran Diponegoro ini merupakan kesempatan yang baik untuk membina kerja sama dan hubungan masa depan kedua negara antara Indonesia dan Belanda.

Setelah peristiwa pengembalian keris Pangeran Diponegoro tersebut, 
muncul polemik dalam masyarakat perkerisan (https://news.detik.com/beritajawa-tengah/d-4933908/polemik-keasliankeris-milik-diponegoro-yang-dipulang-

kan-dari-belanda/2). Ada yang berpendapat bahwa keris yang dikembalikan tersebut bukan keris Nogo Siluman, tetapi keris Nogososro Kamarogan. Akan tetapi, ada pula yang mengatakan keris yang dikembalikan tersebut adalah keris Nogo Siluman milik Pangeran Diponegoro. Pendapat kedua kelompok masyarakat perkerisan ini, tentunya didasari oleh argumentasi yang mendukung pendapat mereka.

Berdasarkan penjelasan tersebut, keris merupakan salah satu bahan kajian yang menarik untuk diteliti dan didiskusikan, baik dari segi akademis maupun non-akademis. Hal ini disebabkan keris mengandung nilai simbolis, filosofis, estetis, mistis, dan sampai saat ini masih banyak orang yang menyimpan atau mengoleksi keris yang merupakan salah satu hasil kebudayaan bangsa Indonesia. Terlebih lagi setelah UNESCO memasukkan keris sebagai salah satu dari sembilan warisan budaya dunia non-bendawi ke dalam daftar Intangible Cultural Heritage yang telah diakui secara resmi pada 25 November 2005 (https://www.kediripedia. com/ unesco-mengakui-keris-sebagai-warisandunia/). Fakta tersebut membuat banyak orang semakin penasaran untuk mengetahui dan mendalami keris lebih lanjut.

Menurut salah seorang tokoh perkerisan Indonesia, Haryono Hargoguritno

(http://www.kemenpar.go.id/post/seminarbudaya-keris-sebagai-warisan-budaya-takbenda-indonesia), pengusulan keris ke UNESCO sehingga diakui sebagai warisan budaya takbenda (intangible) antara lain mencakup sejarah, tradisi, fungsi sosial, teknik tempa, estetika, falsafah, simbol dan mistik perkerisan
Indonesia. Konsekuensi dari pengakuan tersebut adalah bahwa bangsa Indonesia berkewajiban untuk menjaga, melestarikan, dan mengembangkan perkerisan yang ada di Indonesia.

Berkaitan dengan pengembangan perkerisan yang ada di Indonesia, saat ini dikenal dengan istilah keris tangguh kamardikan. Keris tangguh kamardikan adalah keris yang dibuat pada masa sekarang atau keris yang dibuat pada masa kemerdekaan atau setelahnya dan bertujuan untuk melestarikan seni perkerisan

(https://sites.google.com/site/thomchrists/ Keris-Jawa-Spiritual-Kebatinan/Keris-

Kamardikan). Secara historis, keris tangguh kamardikan merupakan kelanjutan dari tangguh (jaman) keris sebelumnya dan bagian dari warisan nenek moyang yang berupa budaya bendawi. Sebagai budaya bendawi keris kamardikan memiliki, bentuk, teknik, dan fungsi dengan ciri-khas dan keunikan sendiri (Wasi Darmojo, 2013:iv).

Salah satu keunikan keris tangguh kamardikan adalah adanya tambahan hiasan inskripsi (tulisan) Arab yang terdapat pada bagian gonjo maupun bilah keris yang diperkirakan sebagai pamornya. Menurut Kusumah, dkk., (1997:8), menorehkan aksara pada berbagai macam media, termasuk keris kamardikan, merupakan bentuk ungkapan penyampaian pesan yang otentisitasnya terjaga dan terawetkan.

Penulisan tulisan pada media, temasuk bilah keris, ini merupakan kelanjutan tradisi penulisan inskripsi Arab pada masa sebelumnya, yaitu masa Turki Usmani. Pada masa tersebut, berbagai macam senjata, seperti meriam, tombak, dan pedang banyak dihiasi dengan inskripsi Arab. Sebagai contoh dapat diberikan, misalnya meriam peninggalan Turki Usmani yang tersimpan di Museum Paris berikut. 


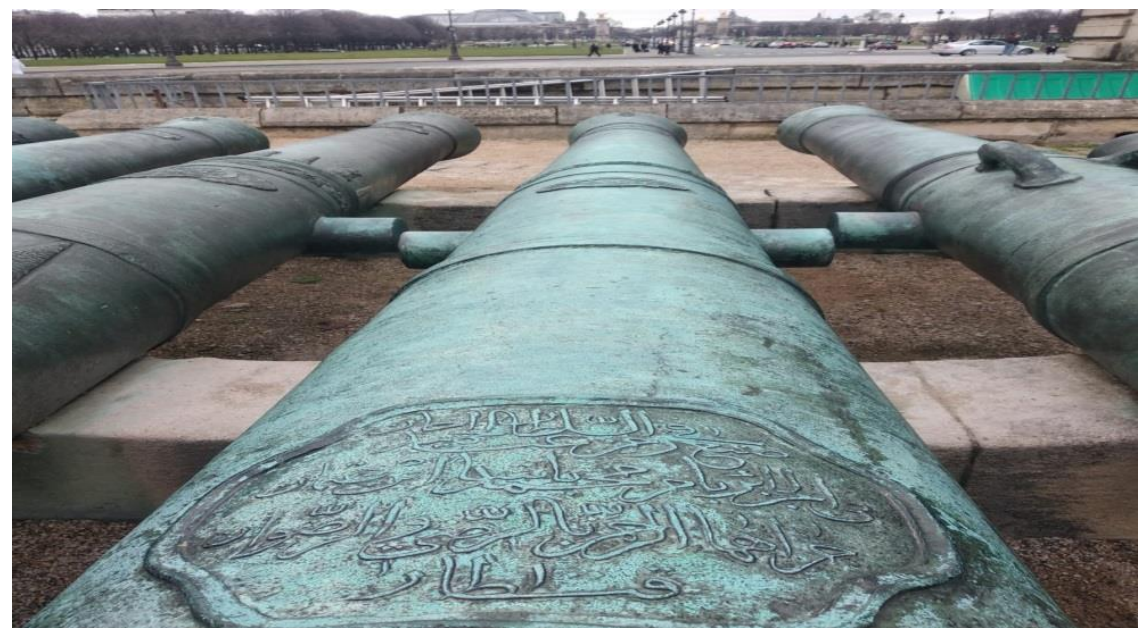

Foto 1. Meriam Berinskripsi Arab di Museum Paris.

(Dokumentasi: Tohir Mustofa, 16 Januari 2020)

Inskripsi Arab pada meriam tersebut ditulis dengan gaya tulisan Arab sulusi dan terbaca:

/Șuni'a fì zamani Sultān Abdu al-Hamīd Khān, fî̀ al-Jazā'ir bi amri Muhammad Bāshā Ibn 'Usmān, jazāhumā ar-raḥmān bi ar-rị̣̄a wa aș-sawāb, 100 qintāran/ '(Meriam ini) dibuat di masa Sultan Abdul hamid Khan di Aljazair atas perintah Muhammad Basya Ibn Usman, semoga keduanya dikaruniai oleh Tuhan
Yang Maha Pengasih keridhaan dan kebenaran, (dengan berat) 100 kuintal'

Di samping itu, inskripsi Arab juga banyak menghiasi senjata yang lain, seperti pedang para sultan Turki Dinasti Ustmaniyyah. Pedang-pedang tersebut sekarang disimpan di salah satu museum di Turki. Salah satu contoh pedang berinskripsi Arab dari masa Dinasti Utsmaniyah adalah, seperti pada foto 2 berikut ini.

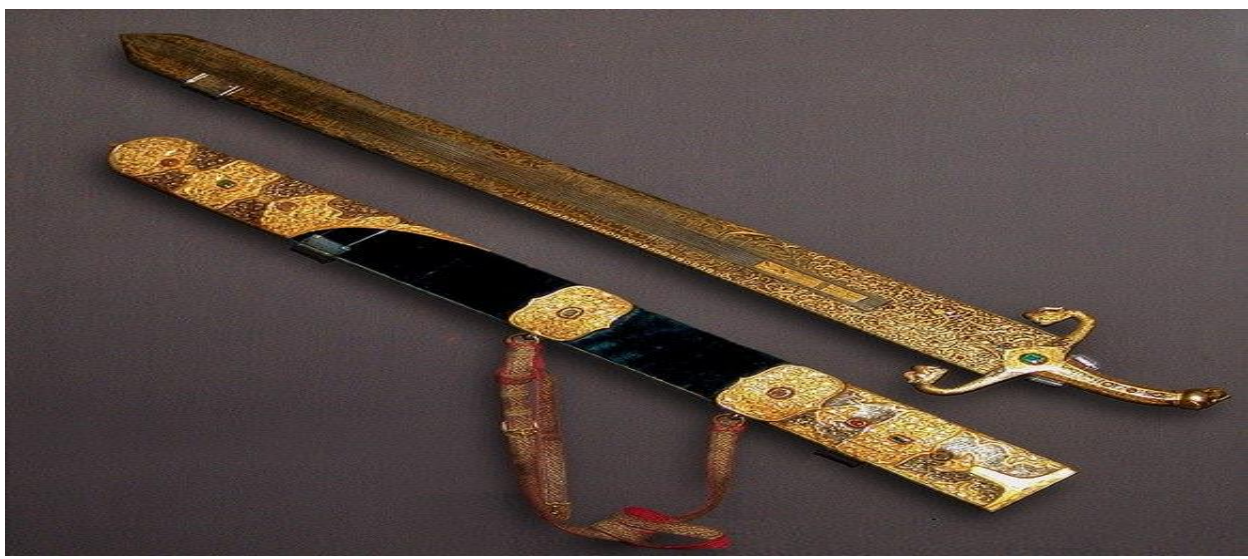

Foto 2. Pedang Dinasti Utsmaniyyah

Sumber: https://id.wikipedia.org/wiki/Pedang_Osman

Pedang pada foto 2 tersebut dihiasi ukiran emas dan permata batu mulia. Pada bagian bilah pedang dihiasi dengan ukiran emas dengan inskripsi Arab yang dengan gaya tulisan $\dot{S} u l u \dot{s} \bar{i}$ dari Alquran surat Al-Fath ayat 1-3, yaitu:

/Bismillāhi ar-rahmāi ar-rahìmi. Innā fatahnā laka fatḥan mubiñā.
Liyagfira laka Allāhu mā taqaddama min zanbika wa mā ta"'akhkhara wa yutimma ni'matahu 'alaika wa yahdiyaka sirātan mustaqīma. Wa yanșuruka Allāhu nașran 'azizal

'Dengan menyebut asma Allah Yang Maha Pengasih lagi Maha Penyayang. (1) Sesungguhnya Kami telah 
memberikan kepadamu kemenangan yang nyata, (2) supaya Allah memberi ampunan kepadamu terhadap dosamu yang telah lalu dan yang akan datang serta menyempurnakan nikmat-Nya atasmu dan memimpin kamu kepada jalan yang lurus, (3) dan supaya Allah menolongmu dengan pertolongan yang kuat (banyak) (Surat AlFath, 1-3).

Karena kerajaan-kerajaan Islam Nusantara dahulu menjadi wilayah kekuasaan Turki Usmani maka budaya menuliskan inskripsi Arab pada senjata juga mempengaruhi tradisi penulisan senjata di Nusantara, seperti keris, pedang, tombak, dan meriam. Hal ini seperti yang ditemukan pada masa Kesultanan Cirebon dan Demak (Abdilllah, 2020). Penulisan inskripsi Arab pada senjata tradisional, khususnya keris, tersebut sampai sekarang masih berlanjut.

Untuk menuliskan inskripsi Arab pada bilah keris diperlukan keahlian khusus dari para seniman Islam, yang juga empu, untuk memperindah keris dengan berbagai macam tulisan Arab (Jawat Nur, 2010:1). Teknik yang digunakan dalam penulisan inskripsi Arab pada keris adalah teknik sinarasah. Menurut Harsinuskmo (2004: 430), sinarasah merupakan teknik yang dipakai untuk menambah hiasan emas, perak, atau logam lain pada permukaan bilah keris, dengan membuat alur atau guratan. Saat ini, keris tangguh kamardikan dengan inskripsi Arab ini banyak dihasilkan oleh para empu dari Madura, dan sudah banyak pula masyarakat yang mengoleksinya. Sudah barang tentu, penambahan inkripsi Arab tersebut mempunyai makna dan maksud tertentu.

Keris kamardikan berinskripsi Arab tersebut sampai sekarang masih banyak dikoleksi atau disimpan para pemiliknya dan dipercaya mempunyai kekuatan magis atau kekuatan supranatural tertentu. Oleh karena itu, tulisan Arab pada keris itu memiliki keeksotisan tersendiri. Dikatakan eksotis karena memiliki daya tarik khas dan belum banyak dikenal oleh masyarakat umum (https://kbbi.web.id/eksotis). Masyarakat awam belum banyak yang mengetahui jenis tulisan dan apa yang dituliskan pada bilah keris kamardikan tersebut.

Berdasarkan hasil studi kepustakaan yang dilakukan diketahui bahwa penelitian tentang inskripsi Arab pada bilah keris belum dilakukan oleh peneliti yang lain. Adapun penelitian yang dilakukan terkait dengan keris sudah dilakukan oleh peneliti lain, antara lain seperti penelitian Musadad (2008), Warto (2008), Jawat Nur (2010), Priyanto (2013), Astuti (2013), Munir (2015), Purnawibawa (2016), Saktimulya (2019).

Musadad (2008) meneliti makna keris dan pengaruhnya terhadap masyarakat di Surakarta. Dalam penelitian tersebut disimpulkan bahwa keris telah dikenal oleh bangsa Indonesia sejak bangsa Indonesia mengenal besi. Pada masa kerajaan Hindu dan Islam, para prajurit mengenakan keris sebagai senjata tradisional. Sampai sekarang keris dianggap mempunyai kekuatan magis yang didasarkan pada bentuk atau pamornya. Daya magis keris ada yang bersumber dari berkah Tuhan, kesaktian empu pembuatnya, maupun dari makhluk halus.

Warto (2008) meneliti makna disain keris dalam budaya Jawa. Dalam penelitiannya, Warto menyimpulkan bahwa ada tiga pandangan terkait dengan dunia perkerisan, yaitu: (a) keris merupakan hasil kebudayaan dan kesenian, (b) keris merupakan senjata pusaka tradisional yang mempunyai daya gaib atau tuah, dan (3) keris merupakan senjata pusaka yang mempunyai makna historis, sosial, etis, filosofis, dan mistisreligius.

Jawat Nur (2010) meneliti kaligrafi Arab pada bilah keris yang ditinjau dari kajian grafemis dan fonologis. Penelitian tersebut menyimpulkan bahwa ditinjau dari segi grafemis, kaligrafi Arab pada keris yang ditemukan adalah jenis kaligrafi naskhî. Adapun muatan tulisan pada bilah keris terdiri dari ayat-ayat suci Al-Qur'an, alasmā' al-ḥusnā, dan rajah tolak bala. 
Astuti (2013) dalam skripsinya meneliti pergeseran makna dan fungsi keris bagi masyarakat Jawa. Penelitian tersebut menyimpulkan bahwa ada pergeseran makna dan fungsi keris dari zaman dahulu dan zaman sekarang. Pergeseran makna dan fungsi keris tersebut disebabkan oleh adanya kemajuan ilmu dan teknologi, serta sistem pemerintahan saat ini.

Priyanto (2013) meneliti keris sebagai salah satu kebudayaan materi yang dikelola museum. Penelitian tersebut menyimpulkan bahwa keris sebagai salah satu kebudayaan materi yang menjadi koleksi museum dipandang sebagai benda cinderamata, jimat, dan benda koleksi itu sendiri. Museum diharapkan dapat memberikan informasi terkait makna keris bagi masyarakat pendukungnya.

Munir (2015) dalam skripsinya meneliti keris berdasarkan pemahaman MT Arifin dalam tinjauan Islam. Penelitian tersebut menyimpulkan bahwa keris merupakan senjata khas suku Jawa yang dibuktikan dengan adanya reliefrelief yang ada pada candi-candi di pulau Jawa. Fungsi keris saat ini adalah sebagai benda seni yang mengandung makna pasemon. Manfaat sebilah keris dalam pandangan Islam adalah sebagai alat pelindung diri suatu ancaman.

Purnawibawa (2016) meneliti analisis kandungan unsur dan tingkat kekerasan pada senjata logam koleksi museum Tosan Aji Purworejo. Penelitian tersebut mengkaji teknologi pembuatan senjata logam pada masa lampau, seperti keris, pedang, dan mata tombak. Hasil penelitian tersebut menyimpulkan bahwa tidak ada hubungan antara hiasan pamor pada senjata logam dan tingkat kekerasan unsurnya. Di samping itu, ditemukan perbedaan tingkat kekerasan pada jenis senjata logam tertentu, dan ditemukan pula tingkat kekerasan dengan proses pembuatan senjata logam tertentu.

Saktimulya (2019) meneliti keris dalam naskah-naskah kuna dalam perspektif mengolah ketajaman pikir dan kelembutan hati. Penelitian tersebut menyimpulkan bahwa dalam naskahnaskah kuna ditemukan kajian tentang keris yang ditinjau dari dhapur, empu pembuatnya, jenis besi yang digunakan untuk membuat keris, tokoh-tokoh yang menggunakan keris, serta sesaji dan mantera dalam pembuatan keris. Dalam penelitian tersebut juga dijelaskan metafora tentang keris yang dimuat dalam Babad Sinelan Nasekah, Babad Matawis saha Candra Nata, dan Sastra Ageng Adidarma.

Berdasarkan studi kepustakaan tersebut dapatlah diketahui bahwa penelitian tentang eksotika inskripsi Arab pada bilah keris kamardikan belum pernah dilakukan oleh peneliti sebelumnya. Oleh karena itu, penelitian ini layak untuk dilanjutkan dan dilaksanakan.

Terkait dengan penjelasan di atas, maka masalah yang akan dikaji dalam penelitian ini adalah (1) jenis inskripsi Arab apa saja yang ada pada bilah keris kamardikan, dan (2) apa fungsi keris berinskripsi Arab bagi para pemiliknya ditinjau dari kajian sosiopragmatik?

\section{B. Kajian Teori dan Kerangka Berfikir 1. Keris}

Keris merupakan senjata tajam bersarung, berujung tajam, dan bermata dua (bilahnya ada yang lurus, ada yang berkeluk-keluk) (https://kbbi. web.id/keris). Warto (2008:114) menambahkan keris ialah sejenis senjata pendek kebangsaan Melayu yang digunakan sejak lebih dari 600 tahun yang lalu. Senjata ini memang unik di wilayah Melayu dan bisa didapati di kawasan berpenduduk Melayu seperti Malaysia, Indonesia, Singapura, Thailand Selatan, Filipina Selatan (Mindanao), dan Brunei. Beberapa sumber (https://www.kompasiana. com/meditasi/582977d26e7e619909c5365 5/keris-sebagai-warisan-budaya-duniamilik-indonesia; Harsrinuksmo (2004:233) menyebutkan bahwa keris merupakan senjata tradisional khas Indonesia, karya seni, sekaligus benda budaya asli Indonesia dengan banyak fungsi budaya yang dikenal di kawasan 
Nusantara bagian barat dan tengah. Dalam perkembangannya, budaya keris menyebar ke luar wilayah Indonesia, seperti Malaysia, Brunai Darussalam, Filipina (Al-Mudra, 2004).

Secara etimologis, istilah keris berasal dari dua kata, yaitu sinengker yang berarti 'rahasia atau disembunyikan' dan kata aris yang berarti 'bijaksana, hati-hati' (http://sejarahharirayahindu.blogspot.com/ 2012/04/keris.html). Berdasarkan etimologi ini maka diharapkan orang yang memiliki atau memegang keris mempunyai sikap yang rendah hati, tidak suka menonjolkan diri, tidak sombong, bijaksana, hati-hati, penuh perhitungan dalam bertindak.

Di samping itu, keris juga mempunyai padanan yang lain, yaitu dhuwung dan curiga. Kata dhuwung berasal dari bahasa Jawa Kuna, dhuhung yang berarti 'keris' (Argawa, 1995:5). Adapun penyebutan curiga diserap dari bahasa Sansekerta curika yang berarti 'keris, pisau' (Argawa, 1995:6). Oleh karena itu, sampai saat ini dalam masyarakat Jawa dikenal pula dengan keris, dhuwung, dan curiga.

Berkaitan dengan istilah keris ini, ada perbedaan pendapat disampaikan oleh para ahli, apakah ditulis kris, seperti yang digunakan oleh Raffles (1817), Wallace (1869), McNair (1882), atau kriss, seperti yang digunakan oleh Forbes (1885), Huyser (1918), dan Buttin (1933). Adapun para ahli yang menggunakan istiah keris di antaranya adalah Wolley, Hill, Gardner, dan Garret (Harsrinuksmo, 2004:234). Istilah keris sampai sekarang lebih populer dan lebih banyak digunakan daripada istilah kris atau kriss.

Dewasa ini, di wilayah Jawa Tengah dan Daerah Istimewa Yogyakarta masih ditemukan para mpu pembuat keris. Para mpu pembuat keris di wilayah Surakarta bisa disebutkan, seperti Mpu Fauzan, Mpu Subandi, dan Mpu Teguh. Sementara itu para mpu pembuat keris di wilayah DIY, seperti Mpu Sungkowo, Mpu Ngadeni, dan Mpu Puryadi. Keriskeris hasil karya mereka biasa disebut dengan keris kamardikan, karena keriskeris tersebut dihasilkan pada masa setelah Indonesia merdeka atau pada masa sekarang ini. Keris kamardikan juga dihasilkan oleh para perajin keris, seperti di wilayah Madura. Dengan demikian, dapatlah dikatakan bahwa keris kamardikan itu merupakan hasil cipta karya para mpu dan juga para perajin keris. Di samping itu, Keris kamardikan yang berasal dari wilayah Madura banyak yang ditulisi dengan tulisan Arab di bagian bilah maupun di bagian gonjo-nya. Tulisan atau inskripsi Arab pada keris kamardikan ini menarik untuk dikaji jenis dan fungsinya.

Karena penelitian ini membahas inskripsi Arab pada keris kamardikan maka perlu kiranya ditentukan batasannya. Hal ini penting untuk menghindari kesalahan dalam pengambilan data. Penentuan kriteria keris yang dijadikan data dalam penelitian ini mengikuti pendapat Harsrinuksmo (2004:9), yaitu sebagai berikut.

a) keris harus terdiri dari dua bagian utama, yaitu bagian bilah keris termasuk pesi dan bagian gonjo.

b) Bilah keris harus selalu membuat sudut tertentu terhadap ganja, tidak tegak lurus.

c) Ukuran panjang bilah keris antara $33 \mathrm{~cm}$ sampai $38 \mathrm{~cm}$.

d) Bahan keris minimal terdiri dari tiga macam loga, yaitu besi, baja, dan bahan pamor; atau minimal terdiri dari besi dan baja.

Berdasarkan kriteria keris tersebut maka keris yang ada inskripsi Arab, tetapi mempunyai ukuran yang kecil dan pendek, terbuat dari bahan kuningan tidak termasuk keris yang dimaksud dalam penelitian ini. Hal ini disebabkan keris jenis ini merupakan keris jimat dan banyak diperjualbelikan di dunia perdukunan.

\section{Sosiopragmatik}

Penelitian eksotika inskripsi Arab pada keris kamardikan ini akan mengkaji tulisan Arab pada bilah keris dan makna tulisan pada keris itu bagi pemiliknya. Oleh karena itu, teori yang digunakan dalam penelitian ini memanfaatkan teori 
sosiopragmatik.

Sosiopragmatik merupakan gabungan dua bidang ilmu, yaitu sosiolinguistik dan pragmatik.

Kridalaksana (1993:201) dan Chaer (2004) menjelaskan bahwa sosiolinguistik merupakan cabang linguistik yang mempelajari hubungan dan saling pengaruh antara perilaku bahasa dan perilaku sosial dalam konteks kebudayaan. Berkaitan dengan hal ini, Aziz (2009:12) menambahkan bahwa sosiolinguistik adalah ilmu yang mengkaji hubungan bahasa dengan masyarakat pemakainya. Adapun pragmatik (Kridalaksana, 1993:177) merupakan ilmu yang menyelidiki pertuturan, konteksnya, dan maknanya. Dengan demikian dapatlah dikatakan bahwa sosiopragmatik merupakan kajian linguistik interdisipliner yang mengkaji pemakaian bahasa yang berhubungan dengan masyarakat beserta konteks budayanya dan mengkaji maksud tuturan berdasarkan konteksnya (Rohmadi, dkk., 2010:7). Gabungan antara sosiolinguistik dan pragmatik inilah yang akan digunakan untuk mengkaji jenis inskripsi Arab pada bilah keris dan fungsinya bagi para pemiliknya.

\section{Pembahasan \\ 1. Inskripsi Arab pada bilah keris kamardikan}

Berbicara mengenai inskripsi Arab, tentunya tidak bisa dilepaskan dari jenis tulisan Arab. Para ahli tulisan Arab telah mengklasifikasikan delapan jenis (Akbar,1995: 25; Ambari, 1997:8-9; Chejne: 1996: 32). Kedelapan jenis tulisan Arab tersebut adalah tulisan Küfi, tulisan Naskhi, tulisan Riq'ah, tulisan Śulusí, tulisan Raihanī, tulisan Dīwāni, tulisan Farisi, dan tulisan Magribï.

Adapun inskripsi atau jenis tulisan Arab pada bilah keris kamardikan yang ditemukan ada dua macam, yaitu keris yang ditulis dengan jenis tulisan Arab satu macam dan bilah keris yang ditulis dengan gabungan beberapa jenis tulisan Arab. Hal tersebut akan diuraikan pada bagian berikut ini.

\section{a. Keris Kamardikan dengan satu jenis tulisan Arab}

1) Jenis tulisan Naskhi

Jenis tulisan naskhi pada keris kamardikan adalah seperti pada (1) berikut.

(1)

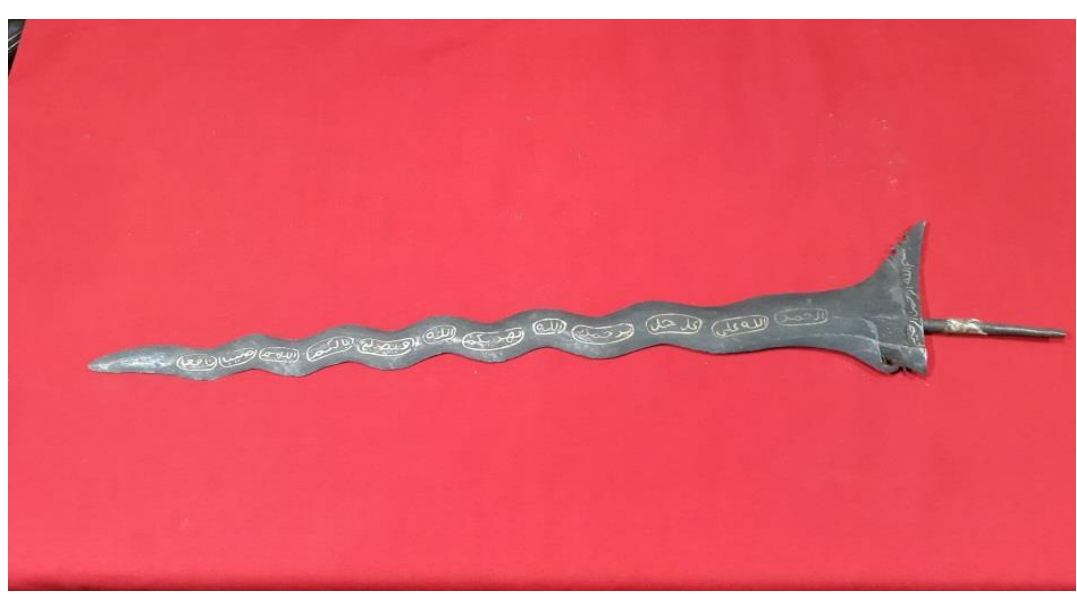

Foto 1. Keris Kamardikan dhapur Lung Gandhu bertulisan Arab gaya Naskh $\bar{i}$

(Dokumentasi Abdul Jawat Nur)

Keris kamardikan pada (1) merupakan keris luk 13 dhapur Lung Gandhu. Jenis tulisan Arab pada (1) adalah tulisan naskhî. Jenis tulisan ini dipakai untuk menulis naskah keagamaan maupun tulisan sehari-hari. Tulisan naskhi sampai sekarang sangat populer digunakan untuk menulis mushaf Alquran. Karakter hurufnya sederhana, nyaris tanpa 
hiasan tambahan, sehingga mudah ditulis dan dibaca (http://arumrum9.blogspot.com/2011/0 9/seni-dan-gaya-penulisan-kaligrafi .html).

Tulisan Arab yang terdapat pada bagian gonjo dan terbaca /bismillähi ar-rahmān ar-rahīm/ 'Dengan menyebut asma Allah Yang Maha Pengasih Maha Penyayang'. Tulisan Arab pada bagian bilah keris tersebut juga menggunakan tulisan naskhi dan terbaca /al-ḥamdu lillāhi 'alā kulli ḥāl yarhamuka Allāh yahdikumullāh wa yuṣlịhu bālakum Allāhumma saiban náfi'an/. Ada lima hal yang dituliskan pada bilah keris tersebut, yaitu: (1) /bismillāhi ar-rahmān ar-rahìm/ sebagai ungkapan doa sebelum melakukan sesuatu, (2) ungkapan doa /al-ḥamdu lillāhi 'alā kulli hạl, (3) ungkapan doa /yarhamuka Allāh /, (4) ungkapan doa yahdikumullāh wa yușlihu bālakum, dan (5) ungkapan doa / Allāhumma sayyiban nāfi'an/.

Ungkapan (1) /bismillāhi arrahmān ar-rahim/ 'Dengan menyebut asma Allah Yang Maha Pengasih Maha Penyayang' merupakan ungkapan yang dianjurkan dalam agama Islam untuk diucapkan sebelum memulai suatu perbuatan. Diantara hadis Nabi Muhammad SAW yang menganjurkan hal tersebut adalah: "Setiap perkara penting yang tidak dimulai dengan 'bismillahirrahmanir rahiim', amalan tersebut terputus berkahnya." (HR. Ahmad)

Ungkapan (2) /al-hamdu lillāhi 'alā kulli hâal/ 'Segala Puja dan Puji milik Allah atas segala keadaan', merupakan ungkapan yang bersumber dari hadis riwayat Ibn Majjah no.3803. Ungkapan ini biasa diucapkan ketika seseorang mendapatkan musibah, mendengar kabar yang kurang baik, ketika sedang bersin, dan ketika sakit atau bersedih. Ini merupakan ungkapan kepasrahan kepada Tuhan dan bentuk syukur kepada-Nya. Walaupun seseorang mendapatkan sesuatu yang tidak disukai, tetapi yang dia ucapkan adalah tetap memuji kebesaran Tuhan, bukan malah mengumpat, meratap ataupun putus asa.

Ungkapan (3) /yarhamuka Allāh/ dan (4) yahdikumullāh wa yuṣlịu bālakum merupakan ungkapan yang bersumber dari hadis HR. Bukhari, no. 6224. Ungkapan ini merupakan tuntunan untuk berdoa ketika ada orang di sekitar kita yang bersin dan jawaban jika ada orang mendoakannya. Di dalam sebuah hadis juga disebutkan bahwa Allah menyukai bersin dan membenci menguap (HR. Bukhari, no. 6223 dan Muslim, no. 2994).

Ungkapan (5) /Allāhumma sayyiban nāfi'an/ Ya Allah, turunkan lah pada kami hujan yang bermanfaat' merupakan salah satu doa yang dianjurkan Nabi Muhammad ketika turun hujan (https://smol.id/2020/03/02/doa-doaketika-turun-hujan/). Ketika hujan turun kita dianjurkan untuk mengucapkan doa tersebut, agar hujan tersebut membawa manfaat dan barakah, tidak membawa bencana dan musibah.

2) Jenis tulisan $D \bar{i} w \bar{a} n \bar{i}$

Keris kamardikan dengan inskripsi Arab jenis Dîiwāni adalah seperti pada foto 2 berikut. 


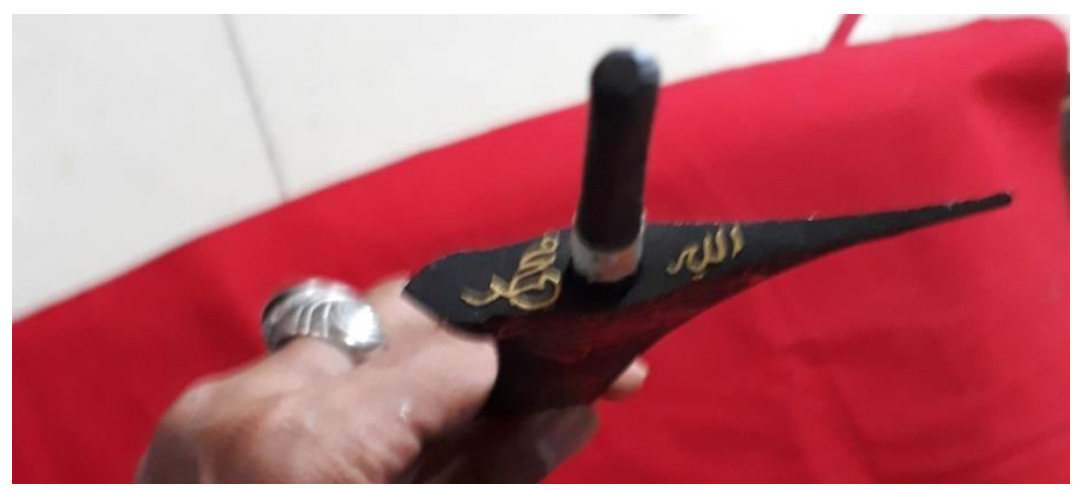

Foto 2. Keris Kamardikan dengan tulisan Arab gaya $\overline{D i} w \bar{n} \bar{i}$ pada bagian gonjo (Dokumentasi Abdul Jawat Nur)

Keris (2) merupakan keris kamardikan, jenis keris lurus, keleng (tanpa pamor), dan pada bagian gonjonya terdapat tulisan Arab jenis Dî́wāni. Tulisan diwānì merupakan jenis tulisan Arab yang berkembang pada masa Turki Usmani. Disebut tulisan Dî̀āni karena pada awalnya tulisan ini digunakan untuk urusan perkantoran (dīwān) (https://kaligrafi-islam.blogspot.com $/ 2015 / 10 /$ kaligrafidiwani-asal-usul-dan-sejarah.html).

Tulisan Dî̀āni digunakan untuk menuliskan dokumen-dokumen diplomatik, kop surat, sampul buku, pemberian ijin, dan lain-lain.

Tulisan Dî́wāni pada gonjo keris tersebut terbaca /Allāh/ dan /Muhammadl. Lafal /Allāh/, menurut al-Bi்rūin (622H:419), merupakan ismul a'zam. Lafal Allah dalam bahasa Arab terdiri atas empat huruf, yaitu alif, dua lam, dan ha. Dikatakan ismul a'zam karena empat huruf Arab itu mampu berdiri sendiri dan masih mempunyai arti yang sama, meski huruf sebelumnya dibuang satu persatu. Lafal الله / Allāh/ jika dibuang huruf alifnya, maka akan menjadi لله /Lillahi/'milik Allah'. Lafal لل /Lillāhi/ dibuang huruf lam-nya, maka akan berbunyi له/Lahu/ 'milik-Nya'. Jika dari lafal /Lahu/ dibuang lagi huruf lam-nya, sehingga hanya tersisa satu huruf saja, yaitu $\mathrm{Hu}$ 'Dia', sebuah kata ganti yang maksudnya kembali kepada lafal Allah. Sebagai bukti, dalam Alquran banyak dijumpai ayat-ayat yang menggunakan ketiga bentuk lafal ini, seperti dalam Alquran surat AlAn'am: 1, Al-An'am: 101, Al-Ankabut: 16.

Dalam ayat Kursi, ketiga bentuk lafadz ini terkumpul dalam satu ayat (https://republika.co.id/berita/ptmq114 58/keistimewaan-lafaz-allah).

Tulisan Arab /Muhammad/ pada gonjo keris (2) juga merupakan jenis tulisan dínāni yang mempunyai ciri gaya tulisan bulat dan tidak berharakat. Keindahan tulisannya bergantung pada permainan garisnya yang kadang-kadang pada huruf tertentu neninggi atau menurun, jauh melebihi patokan garis horizontalnya (http://arumrum9.blogspot.com/2011 09/seni-dan-gaya-penulisan-

kaligrafi.html). Yang dimaksud /Muhammad/ pada gonjo keris (2) ini adalah Nabi Muhammad, nabi penutup para nabi dan rasul.

\section{b. Keris Kamardikan dengan lebih dari satu jenis tulisan Arab}

Di samping ditemukan satu jenis tulisan Arab pada keris, ditemukan juga keris yang bertulisan Arab lebih dari satu jenis tulisan. Hal tersebut seperti yang diuraikan pada bagian berikut ini.

1) Tulisan Naskhī dan Dīwānì

Keris kamardikan yang bertuliskan tulisan Arab dengan tulisan Naskhi dan Dīwāni adalah seperti pada foto (3) berikut ini. 
(3)

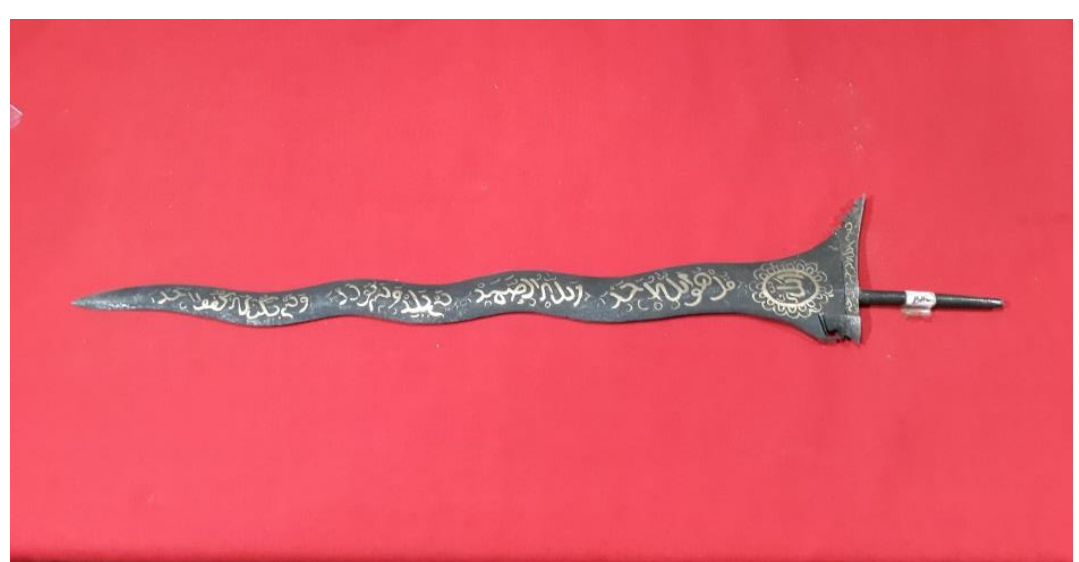

Foto 3. Keris Kamardikan bertuliskan Arab dengan Tulisan Naskhī dan Dïwāni (Dokumentasi Abdul Jawat Nur)

Keris kamardikan pada (3) merupakan keris dhapur sempono (luk 9) bertuliskan Arab jenis tulisan Naskhi dan Dïwāni. Tulisan Naskhì yang terdapat pada bagian gonjo tertulis lafal basmalah tanpa harakat /bismillāhi ar-rahmān ar-rahìm/ 'Dengan menyebut asma Allah Yang Maha Pengasih Maha Penyayang'. Tulisan Naskhi yang lain terdapat pada bagian luk pertama hingga luk ke sembilan merupakan salah satu surat dalam Alquran, yaitu surat al-Ikhlāṣ, terbaca / Qul huwa Allāhu aḥad. Allāhu ass-samad. Lam yalid walam yūlad. Wa lam wakun lahu kufuwan ahadl 'Katakanlah (Muhammad), 'Dialah Allah, Yang Maha Esa'. Allah tempat meminta segala sesuatu. (Allah) tidak beranak dan tidak pula diperanakkan. Dan tidak ada sesuatu yang setara dengan Dia'. Tulisan Naskhi pada bilah keris tersebut masih tampak tidak halus, tidak memperhatikan tebal tipisnya huruf.

Adapun tulisan $\overline{D i} w \bar{n} \bar{i} \bar{i}$ terdapat pada bagian sor-soran (di atas gonjo) terbaca /Allāh/ dengan harakat di dalam lingkaran yang berhias setengah bulatan dua lapis. Tulisa Dî̀āni tersebut masih terlihat kurang halus tebal tipisnya.

2) Jenis tulisan Naskhi, Tugrā, dan Śulusi $i$

Keris kamardikan yang bertuliskan Arab jenis Naskhi, Tugrä, dan Śulusi adalah seperti pada (4) berikut.

(4)

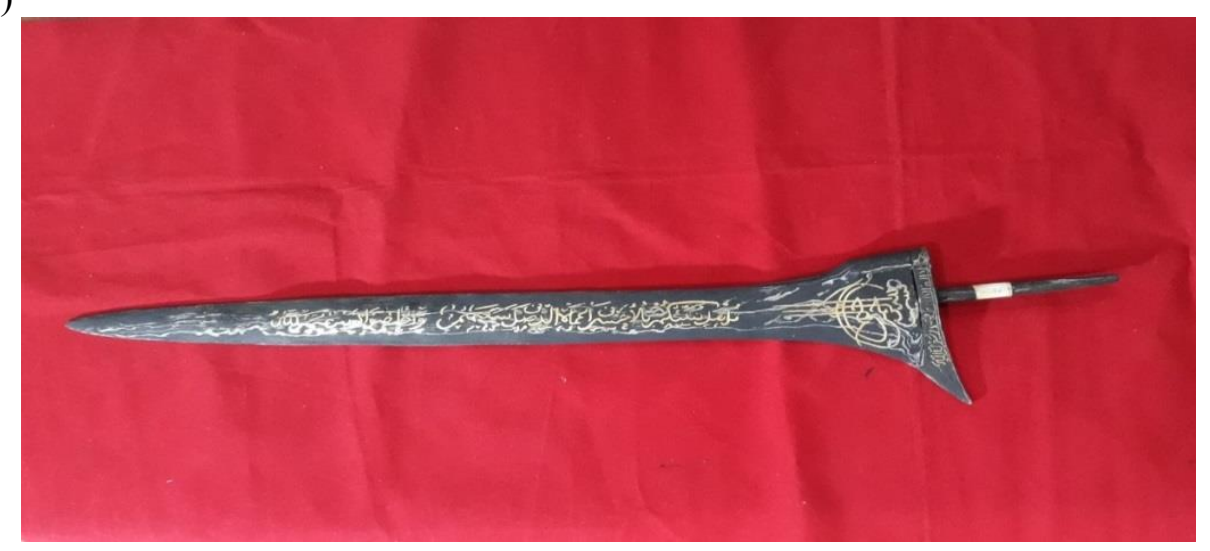


Foto 4. Keris Kamardikan dhapur brojol dengan tulisan Arab jenis Naskhi, Ṭugrā, dan Śuluśi. (Dokumentasi Abdul Jawat Nur)

Tulisan Arab pada keris kamardikan (4) merupakan gabungan tiga jenis tulisan Arab, yaitu tulisan Naskhi, Tugrā, dan Ś uluśi. Keris (4) tersebut merupakan jenis keris lurus dhapur brojol, berpamor ngulit semongko. Tulisan Naskhi tanpa harakat yang terdapat pada bagian gonjo terbaca /L̄̄ ilāha illallāh Muhammad rasūlullāh/ 'Tidak ada Tuhan selain Allah, Muhammad adalah utusan Allah'. Ungkapan / L $\bar{a}$ ilāha illallāh Muhammad rasūlullāh/ merupakan kalimat tauhid yang merupakan pondasi agama Islam dan merupakan rukun yang pertama dari kelima rukun Islam.

Tulisan Tugrā tanpa harakat dan hiasan pada keris (4) terdapat pada bagian sor-soran keris. Tulisan Tugrā merupakan salah satu kreasi jenis tulisan Arab. Jenis tulisan ini pernah menjadi kebanggaan para kaligrafer masa Turki Usmani. Pada awalnya jenis tulisan ini dipakai sebagai stempel atau tanda tangan para penguasa Turki Usmani (https://kaligrafi-islam.blogspot.com/search/label

(5)

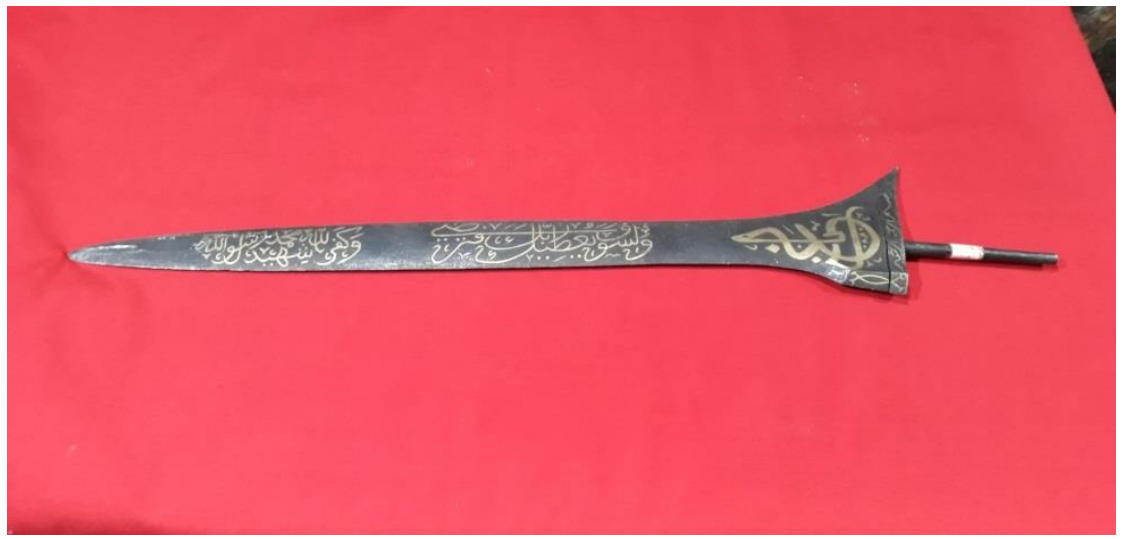

Foto 5. Keris Kamardikan dengan tulisan Arab gaya tulisan Naskhï, Tugrä, dan Raihanī (Dokumentasi Abdul Jawat Nur)

Foto (5) merupakan keris kamardikan jenis keris lurus, dhapur brojol tanpa pamor. Pada bagian gonjo terdapat tulisan Arab gaya naskhi
/Tughra). Tulisan Tugrā pada sorsoran keris (4) terbaca /bismillāhi arrạ̣mān ar-rahịm/ 'Dengan menyebut asma Allah Yang Maha Pengasih Maha Penyayang'.

Di samping itu, pada kedua bilah keris (4) terdapat tulisan Śulusi lengkap dengan harakat dan hiasan. Tulisan tersebut terbaca: /Qul hal nunabbi'ukum bi al-akhsarīna a'mālà . al-lazina dalla sa'yuhum/. Tulisan tersebut merupakan tulisan surat alKahfi ayat 103 dan sebagian dari surat al-Kahfi ayat 104 .

Pada bagian atas tulisan tersebut terdapat tulisan Śulusi i terbaca / wa akhlașū dinahum lillāh/'Mereka tulus ikhlas (mengerjakan) agama mereka karena Allah'. Tulisan ini merupakan bagian dari Alquran surat An-Nisā': 146.

3) Jenis tulisan Naskhī, Tugrā, dan Raihan $\bar{i}$

Jenis gabungan tulisan Arab yang ditemukan pada keris kamardikan adalah jenis tulisan Naskhī, Tugrā, dan Raihani, seperti pada (5) berikut. 
terdapat pada bagian sor-soran tanpa harakat, dengan hiasan terbaca /yâ Ganiyyu/ 'Wahai Tuhan Yang Maha Kaya' yang merupakan salah satu dari sembilan puluh sembilan asma Allah atau al-asmā' al-ḥusnā. Sementara itu pada bagian bilahnya terdapat tulisan Raihani lengkap dengan harakat dan hiasan. Tulisan Raihan̄i yang pertama terbaca /walasaufa yu'tika rabbuka fatardā/ 'Dan sungguh, kelak Tuhanmu pasti memberikan karuniaNya kepadamu sehingga engkau menjadi puas' (Q.S. Aḍ-Duhāa: 5). Tulisan Raihani $\bar{i}$ kedua menghiasi bilah keris bagian atas. Tulisan tersebut terbaca /wa kafā billāhi syahïdan Muhammad rasūlullāh/ 'Cukuplah Allah sebagai saksi Muhammad rasul Allah'. Tulisan /wa kafá billāhi syahidan/ merupakan petikan ayat Alquran surat an-Nisa ayat 79, sedangkan /Muhammad rasūlullāh/ adalah petikan ayat Alquran surat alFath ayat 29.

4) Tulisan naskhī dan Diwanì Jali Keris kamardikan yang bertuliskan Arab jenis naskhi dan Diwani Jali adalah seperti pada foto (6) berikut.

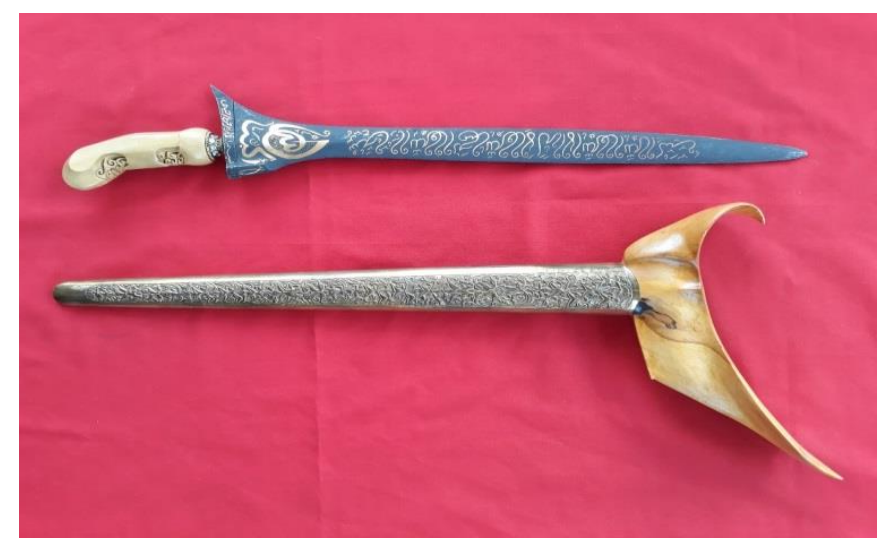

Foto 6. Keris Kamardikan dengan tulisan Arab jen naskhï dan Diwanì Jali. (Dokumentasi: Abdul Jawat Nur)

Keris pada foto (6) merupakan keris kamardikan jenis keris lurus, dhapur brojol, tanpa pamor. Keris tersebut bertuliskan Arab tanpa harakat jenis naskhi pada bagian gonjo terbaca / bismillāhi ar-rahmān arrahịm/ 'Dengan menyebut asma Allah Yang Maha Pengasih Maha Penyayang'. Pada bagian sor-soran terdapat tulisan Arab jenis diwani jali lengkap dengan harakat dan hiasan. Tulisan tersebut terbaca / Allāhu akbar' 'Allah Maha Besar'. Adapun pada bagian atasnya tertulis / subhānallāh wal hamdu lillāh walà ilāha illallāh Allāhu akbart 'Maha Suci Allah dan segala puji bagi Allah dan tidak ada Tuhan Selain Allah, Allah Maha Besar'.

\section{c. Tulisan Rajah}

Selain berbagai jenis tulisan Arab yang ditemukan pada keris kamardikan, ditemukan juga tulisan rajah. Dalam Kamus Besar Bahasa Indonesia disebutkan bahwa rajah adalah suratan atau gambaran, tanda, dan sebagainya yang dipakai sebagai azimat untuk keselamatan, penolak penyakit, bahaya, dan sebagainya (https://kbbi.web.id/ rajah). Keris kamardikan yang bertuliskan rajah adalah seperti pada foto (7) berikut. 


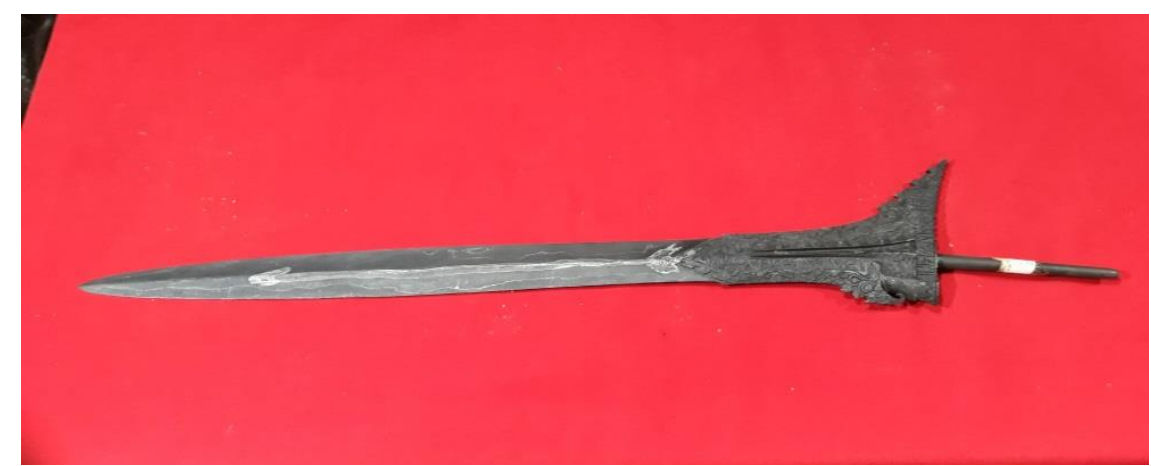

Foto 7. Keris Kamardikan dhapur jalak sinom robyong dengan tulisan rajah (Dokumentasi Abdul Jawat Nur)

Keris kamardikan pada foto (7) merupakan jenis keris lurus dhapur jalak sinom robyong, pamor satria pinayungan. Tulisan rajah pada keris (7) dipahatkan dengan halus pada bagian gonjo dan sorsoran. Tulisan rajah pada bagian gonjo tertulis angka-angka Arab / 2284492 $7182421 \%$. Adapun tulisan pada sorsoran ada empat kelompok angka yang ditulis ke atas, yaitu: (1) /849845122689111484838/, (2) /68284/, (3) 1748 $828 /$,

/1492719714349834818/. Dengan demikian tulisan rajah tersebut hanya bisa dibaca angka-angkanya saja, tetapi tidak diketahui pesan yang ingin disampaikan kepada pembacanya.

\section{Fungsi Inskripsi Arab pada Bilah Keris bagi Pemiliknya}

(8)

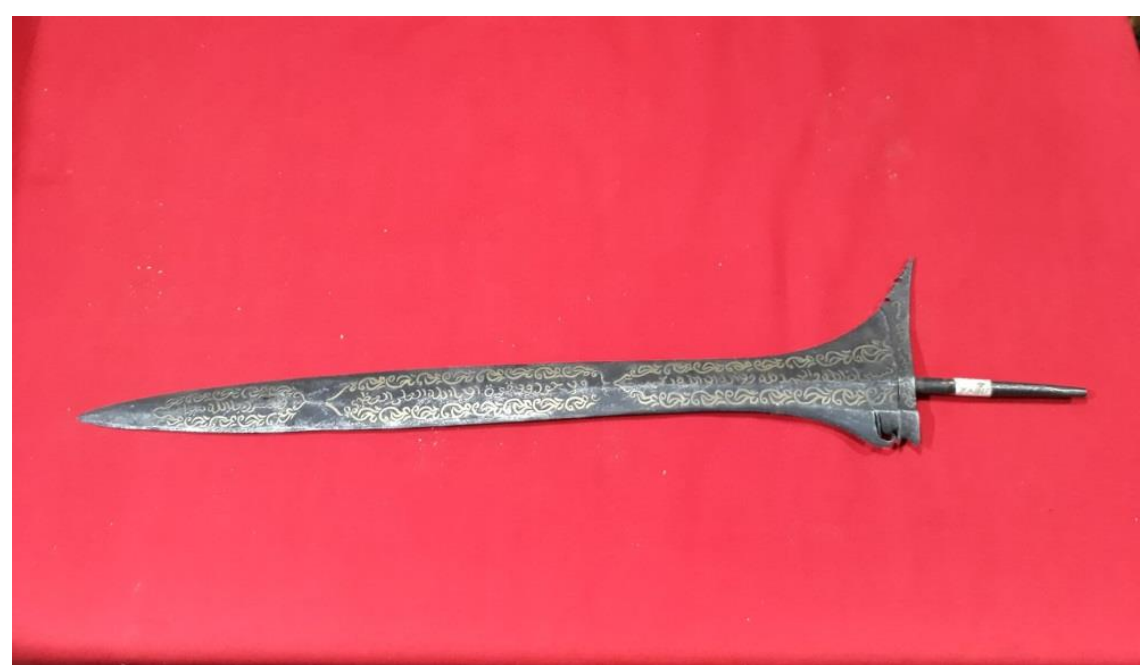

Foto 8. Keris tangguh kamardikan dhapur sempaner berinskripsi Arab jenis naskhi (Dokumentasi Abdul Jawat Nur) yang dikumpulkan dari para pemilik keris kamardikan yang berinskripsi Arab diketahui bahwa mereka menyimpan atau mengoleksi keris tersebut mempunyai maksud tertentu yang terkait dengan fungsi tulisan Arab pada keris. Adapun maksud mereka mengoleksi keris kamardikan berinskripsi Arab adalah karena keris tersebut mempunyai fungsi estetis, fungsi simbolis, fungsi keselamatan, dan fungsi kesuksesan. Adapun penjelasannya adalah sebagai berikut.

\section{a. Fungsi Estetis}

Keris kamardikan berinskripsi Arab yang mempunyai fungis estetis adalah seperti pada foto 8 berikut. 
Foto 8 merupakan keris kamardikan dhapur sempaner, termasuk jenis keris lurus. Tulisan pada keris tersebut adalah jenis tulisan naskhi tanpa vokalisasi (harakat). Pada bagian gonjo bertuliskan / bismillāhi ar-raḥmāni ar-rahịmil 'Dengan menyebut asma Allah Yang Maha Pengasih Maha Penyayang'. Pada bagian bilah keris terdapat tiga tulisan Arab yang dibatasi oleh hiasan sulur-suluran. Bagian pertama terbaca /subhānallāh wa alhamdu lillāh walā ilāha illallāhu Allāhu akbar' 'Maha Suci Allah segala puji bagi Allah, Allah Maha Besar'. Bagian kedua terbaca / walā haula walā quwwata illā billāhi al-'aliyyi al-'azìm / 'Tidak ada daya dan upaya kecuali dari Allah Yang Maha Kuasa' 'sedangkan pada bagian ketiga tertulis /lā tusyrik billāhi yaqīnăl 'Janganlah menyekutukan Allah seyakinyakinnya'.

Keris pada foto 8 adalah keris kamardikan koleksi bapak Jumani. Berdasarkan hasil wawancara dengan pemilik keris tersebut diperoleh kesimpulan bahwa maksud mengoleksi keris berinskripsi Arab tersebut karena keindahan tampilan keris tersebut. Apa yang disampaikan Pak Jumani tersebut sejalan dengan pengertian estetika, yaitu pemahaman tentang keindahan serta rasa pengapresiasian terhadap seni (Hasanudin, 2014: 310). Suatu objek dikatakan estetis jika memenuhi beberapa unsur, antara lain: unsur bentuk, warna, tema, motif hias (https://www.dosenpendidikan.co.id/estet ika-adalah/ftoc-heading-10). Bila dilihat dari bentuknya, inskripsi Arab pada bilah keris tersebut mempunyai nilai estetis karena bentuk tulisannya mempunyai daya tarik bagi orang yang melihatnya. Warna tulisan Arab yang keemasan menambah keindahan keris tersebut karena kontras dengan warna bilah keris yang keleng (hitam). Tema atau ide gagasan yang ingin disampaikan kepada orang lain pada inskripsi Arab tersebut adalah (a) jangan lupa menyebut asma Allah ketika akan memulai melakukan sesuatu dengan bacaan /bismillāhi arraḥmāni ar-rahīmil 'Dengan menyebut asma Allah Yang Maha Pengasih Maha Penyayang', (b) selalu mengingat Allah dengan membaca /subhānallāh wa alhamdu lillāh walā ilāha illallāhu Allāhu akbart 'Maha Suci Allah segala puji bagi Allah, Allah Maha Besar, (c) introspeksi diri bahwa manusia itu tidak ada apaapanya di hadapan Allah dengan membaca / walā haula walā quwwata illā billāhi al-'aliyyi al-'azim / 'Tidak ada daya dan upaya kecuali dari Allah Yang Maha Kuasa', dan (d) larangan menyekutukan Allah dalam bacaan /lāa tusyrik billāhi yaqīinal 'Janganlah menyekutukan Allah seyakin-yakinnya'. Unsur motif hias sulur-suluran yang membatasi inskripsi Arab pada bilah keris dimaksudkan untuk menambah nilai keindahan pada keris tersebut.

\section{b. Fungsi Simbolis}

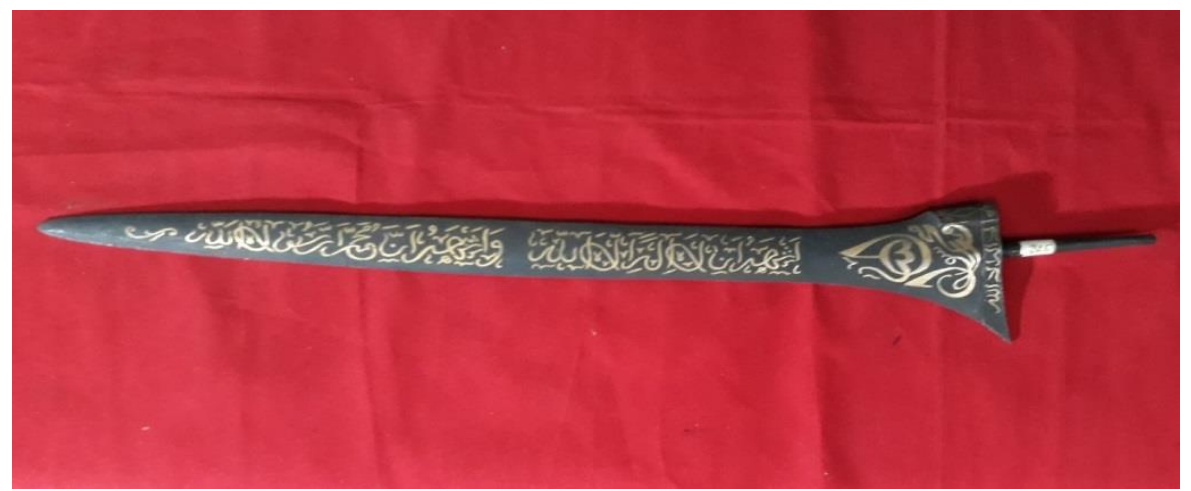

Foto 9. Keris dengan inskripsi Arab sebagai simbol seorang muslim (Dokumentasi Abdul Jawat Nur) 
Keris kamardikan pada foto 9 merupakan keris lurus dhapur brojol. Keris tersebut merupakan keris kamardikan koleksi Bapak Paina. Menurut Bapak Paina, motivasi beliau memiliki keris tersebut karena inskripsi Arab pada keris tersebut merupakan simbol seorang muslim. Hal itu disebabkan pada bagian gonjo terdapat tulisan /lā ilāha illalläh/ 'Tidak ada Tuhan selain Allah', pada bagian sorsoran terdapat tulisan /Muhammad rasūlullāh/ 'Nabi Muhammad adalah utusan Allah' yang keduanya merupakan kalimah tauhid. Adapun pada bagian bilah terdapat tulisan kalimah syahadah I Asyhadu an là'ilāha illallāh Muhammdun rasūlullāh/. Kalimat syahadah adalah dua perkataan pengakuan yang diucapkan dengan lisan dan dibenarkan oleh hati

(10) untuk menjadikan diri orang Islam. Kalimat syahadah merupakan pintu gerbang seseorang menjadi seorang muslim (Labib, 2005:22). Oleh karena itu, maksud Bapak Paina mengoleksi keris kamardikan seperti pada foto 9 sebagai simbol identitas diri sebagai seorang muslim ini sesuai dengan apa yang disampaikan Crystal (2015:21) bahwa penggunaan bahasa dapat mengungkapkan identitas seseorang, baik agama, latar belakang sosial, pendidikan, pekerjaan, jenis kelamin, dan kepribadian. Keris kamardikan dengan inskripsi Arab seperti pada foto 9 biasanya dikoleksi oleh kiai atau ulama.

\section{c. Fungsi Keselamatan}

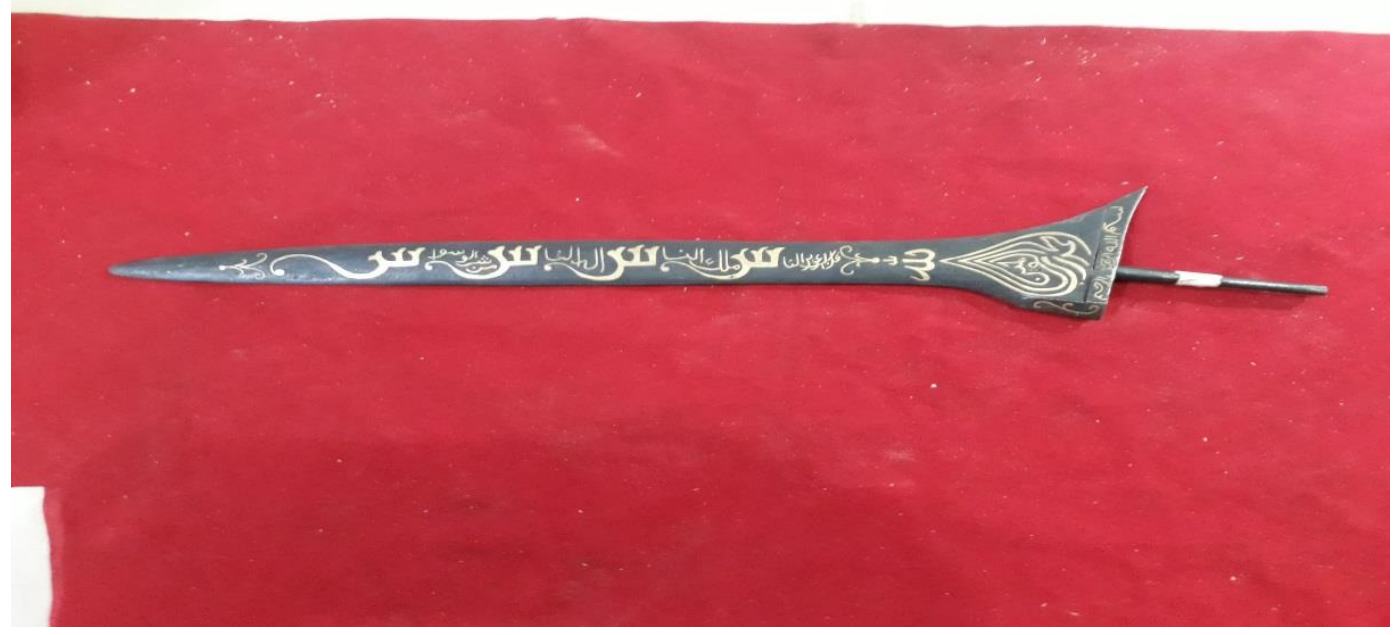

Foto 10. Keris kamardikan dhapur brojol berinskripsi Arab yang dipercaya mempunyai fungsi keselamatan (Dokumentasi Abdul Jawat Nur)

Keris kamardikan pada foto 10 merupakan keris jenis lurus, dhapur brojol, koleksi Bapak Abdillah, seorang pemilik kios keris Intan Pusaka Jaya di Pasar Beringharjo Yogyakarta, serta salah seorang kolektor keris di Yogyakarta. Maksud Bapak Abdillah mengoleksi keris pada foto 10 tersebut karena tulisan Arab pada bilah keris tersebut menunjukkan fungsinya. Hal tersebut juga dipertegas oleh pendapat Bapak Didik dan Mpu Puryadi bahwa fungsi tulisan Arab pada bilah keris itu seperti pamor keris, dan tulisan Arab pada keris itu mempunyai fungsi tertentu.

Tulisan Arab tanpa harakat pada keris foto 10 tersebut terbaca (a) pada bagian ganja terdapat inskripsi /bismillāhirrahmānirrahìm/ 'Dengan menyebut asma Allah Yang Maha Pengasih lagi Penyayang' dengan gaya tulisan naskhi, (b) pada bagian sor-soran terdapat tulisan /al-hamdu lillāhi rabbil 'àlamin/'Segala puji milik Allah, Tuhan seru sekalian alam' dengan gaya tulisan diwani, (c) pada bilah keris tersebut 
terdapat inskripsi Arab sebuah ayat dari Alquran surat an-Nās ayat 1-6, yaitu: / qul a'üzu birabbi an-nās, maliki an-nās, ilāhi an-nās, min syarri al-waswāsi al-khannās, al-lazī yuwaswisu fī sudūri an-nās, min aljinnati wa an-nās/ 'Raja manusia, sembahan manusia, dari kejahatan (bisikan) setan yang bersembunyi, yang membisikkan (kejahatan) ke dalam dada manusia, dari (golongan) jin dan manusia." (QS. An-Nas, 1-6). Menurut Pak Abdillah, inskripsi Arab yang memuat surat an-Nās tersebut pada keris tersebut oleh pemiliknya dipercaya dapat dijadikan sarana untuk melindungi diri

(11)

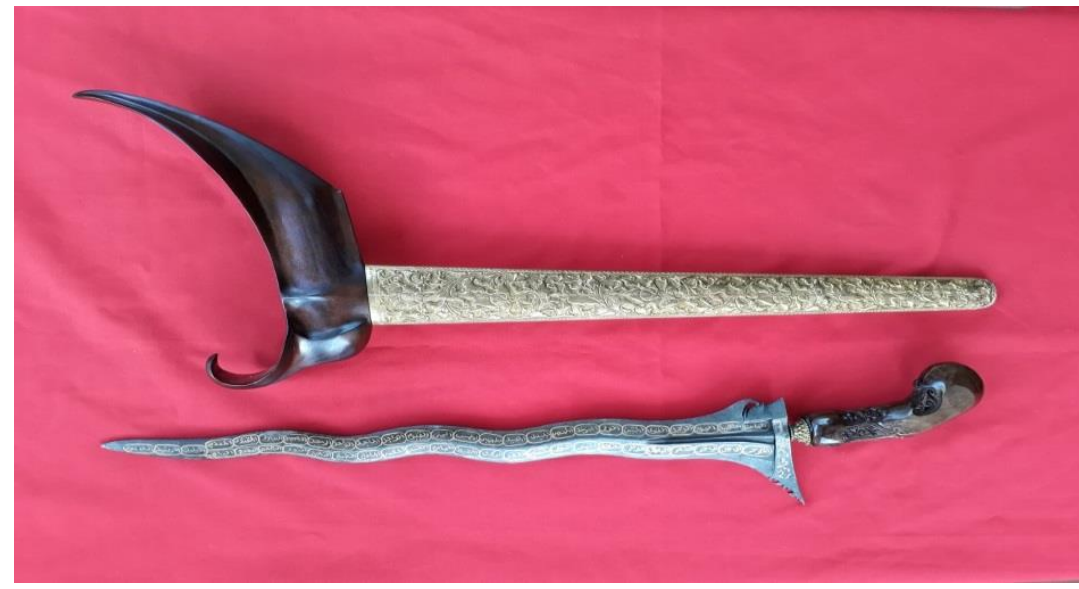

Foto 11. Keris Kamardikan luk sembilan dhapur Jarajeh, bertuliskan al-asmā' al-ḥusnā (Dokumentasi Abdul Jawat Nur)

Keris kamardikan pada foto 11 merupakan jenis keris luk sembilan, dhapur jarajeh, pada bagian gonjo berinskripsikan Arab /Bismillāhi arraḥmāni ar-rahìmil 'Dengan menyebut asma Allah Yang Maha Pengasih Maha Penyayang', dan pada kedua sisi bilahnya bertuliskan al-asmā' al-husnā terbaca:

huwallăhu al-lażi la ilaha illa huwa arrahmanu ar-rahimu al-maliku al-quddusu as-salamu al-mu'minu al-muhaiminu al'azizu al-jabbaru al-mutakabbiru alkhaliqu al-bari'u al-musawwiru al-gaffaru al-qahhäru al-wahhābu ar-razzạqu alfattahu al-'alimu al-qābidu al-basitu alkhäfidu ar-rafi'u al-mu'izzu al-muzillu assamì'u al-basisiru al-hakamu al-'adlu allạtifu al-khäbiru al-halimu al-'ózimu algafuru asy-syaküru al-'aliyyu al-kabiru alhafïzu al-muqitu al-hasibu al-jalilu al- dan keluarga dari energi negatif. Syaikh Ahmad Dairabì al-Kabir dalam Kitāb alMujarrabah (2019:114) menjelaskan bahwa diantara fungsi atau khasiyat surat an-Nās adalah (a) menjauhkan diri dari energi negatif, (b) dikabulkan doanya, (c) dikasihi sesama makhluk, dan (d) untuk tolak balak. Terkait kepercayaan seseorang terhadap kekuatan supranatural yang ada pada benda ataupun tulisan, menurut Crystal (2015:21) termasuk fungsi bahasa sebagai kontrol realitas.

\section{d. Fungsi Kesuksesan}


Berbah, Sleman, Yogyakarta. Menurut Bapak Ferry, keris kamardikan yang bertuliskan al-asmā' al-ḥusnā dia koleksi karena mempunyai fungsi untuk kesuksesan. Hal yang sama juga disampaikan oleh $\mathrm{Bu}$ Dewi yang mempunyai keris kamardikan dengan inskripsi Arab al-asmā, al-husnā. Berkaitan dengan al-asmā' al-ḥusnā, Syaikh Ahmad Dairabi al-Kabir (2019:229) menjelaskan bahwa diantara fungsi atau fadhilah al-asmā' al-ḥusnā adalah sebagai berikut: (a) penyembuh untuk orang yang sakit, (b) diselamatkan dari mara bahaya, (c) dikabulkan doadoanya, (d) sukses dalam menjalankan usaha, (e) mendapatkan ketenangan dan ketentraman hidup atas ijin Allah.

Semua bentuk kepercayaan supranatural yang menggunakan bahasa sebagai sarana untuk mengontrol kekuatan yang oleh orang yang percaya diyakini berpengaruh pada hidupnya tersebut, menurut Crystal (2015:20), merupakan salah satu fungsi bahasa, yaitu fungsi kontrol realitas.

\section{Kesimpulan}

Tradisi penulisan inskripsi Arab pada keris kamardikan merupakan kelanjutan dari tradisi penulisan inskripsi Arab pada masa sebelumnya. Inskripsi Arab pada keris kamardikan mempunyai daya tarik tersendiri untuk dikaji, baik dari segi jenis tulisan Arabnya maupun dari segi maksud atau motivasi para pemiliknya. Di samping itu, penulisan inskripsi Arab pada keris kamardikan merupakan bentuk ungkapan penyampaian pesan agar otentisitasnya terjaga dan terawetkan.

Berdasarkan analisis terhadap jenis tulisan Arab pada keris kamardikan disimpulkan bahwa tulisan Arab di keris kamardikan ada yang menggunakan satu jenis tulisan, yaitu tulisan naskhi dan tulisan diwāni dan ada pula yang menggunakan gabungan dari beberapa jenis tulisan Arab, yaitu (a) tulisan Naskhi dan Dî̀āni, (b) tulisan Naskhi, Tugrā, dan Śulusisi, (c) tulisan Naskhī,
Tugrā, dan Raihanī, (d) tulisan naskhï dan Diwani Jali, dan (e) tulisan rajah.

Berdasarkan

kajian sosiopragmatik, inskripsi Arab pada keris kamardikan mempunyai fungsi (a) estetis, (b) simbolis, (c) keselamatan, dan (d) kesuksesan.

\section{Daftar Pustaka}

Al-Bīrūni, al-Imām Aḥmad, 622H. Syams al-Ma'ārif al-Kubrā wa Lată'if al'Awārif. Bairut: al-Maktabah asySya'biyyah.

Astuti, Murni, 2013. "Pergeseran Makna dan Fungsi Keris bagi Masyarakat Jawa". Skripsi. Program Studi Sastra Indonesia, Jurusan Sastra Indonesia, Fakultas Sastra Universitas Sanata Dharma, Yogyakarta.

Aziz, Abdul Muhammad Husain, 2009. Ilmu al-Lugah al-Ijtimā'î. Kairo: Maktabah al-Adab.

Chaer, Abdul dan Leoni Agustina, 2004. Sosiolinguistik Perkenalan Awal. Jakarta: Rineka Cipta.

Crystal, David, 1992. The Cambridge Encyclopedia of Language. New York: Cambridge University Press.

ad-Dahidāh, Anton, 2001. A Dictionary of Arabic Grammar in Charts and Tables. Bairut: Maktabah Lubnān Nāsyirūn.

Harsrinuksmo, Bambang, 2003. Ensiklopedi Keris. Jakarta: Gramedia.

Jawat Nur, Abdul, 2010. "Kaligrafi Arab pada Keris: Tinjauan Grafemis dan Fonologis". Laporan Penelitian. Yogyakarta: Fakultas Ilmu Budaya UGM.

Kesuma, Tri Mastoyo Jati, 2007. Pengantar (Metode) Penelitian Bahasa. Yogyakarta: Carasvatibooks. 
Kridalaksana, Harimurti, 1993. Kamus Linguistik. Jakarta: Gramedia Pustaka Utama.

Kusumah, Siti Dloyana, dkk., 1997. Indonesia Indah "Aksara". Jakarta: Yayasan Harapan Kita/BP3 TMII.

Labib, 2005. Pilihan Sholat Terlengkap Disertai Doa, Dzikir, Wirid, serta Hikmahnya. Surabaya: Usaha Jaya.

Munir, Muhammad Khafidlil, 2015. "Memahami Konsep Keris Menurut MT Arifin dalam Tinjauan Islam”. Skripsi. Fakultas Ushuluddin dan Humaniora, Universitas Islam Negeri Walisongo Semarang.

Mushaf Alquran Tajwid dan Terjemah tanpa Takwil Asma Wa Sifat, 2013. Jakarta: Alfatih Berkah Cipta.

Musadad, Akhmad Arif, 2008. "Makna Keris dan Pengaruhnya Terhadap Masyarakat di Surakarta" dalam Jurnal MIIPS, Vol 7 Nomor 3, September 2008, 147-156.

Poerwadarminto, WJS. 1987. Kamus Umum Bahasa Indonesia. Jakarta: Pusat Pembinaan dan Pengembangan Bahasa Departemen Pendidikan dan Kebudayaan.

Priyanto, 2013. "Keris sebagai Salah Satu Kebudayaan Materi" dalam Jurnal Vokasi Indonesia, Juornal of Vocational Program University of Indonesia, Vol.1 Nomor 1 Januari-Juni 2013.

Purnawibawa, R Ahmad Ginanjar, 2016. "Analisis Kandungan Unsur dan Tingkat Kekerasan pada Senjata Logam Koleksi Museum Tosan Aji Purworejo" dalam Jurnal Konservasi Cagar Budaya Borobudur, Vol 10, Nomor 2, Desember 2016.
Rohmadi, dkk., 2013. Kajian Pragmatik Peran Konteks Sosial dan Budaya dalam Tindak Tutur Bahasa di Pacitan. Surakarta: Yuma Pustaka.

Saktimulya, Sri Ratna, 2019. "Keris dalam Naskah-naskah Kuna: Mengolah Ketajaman Pikir dan Kelembutan Hati." Makalah pada Hari Kesehatan Nasional dan Sumpah Pemuda dan Disampaikan dalam Seminar Kesehatan dan Pameran Keris: Spiritualitas Jawa dalam Menjaga Kesehatan Menuju Rumah Sakit Berbudaya. Penyelenggara RSUP Dr. Sardjito, Yogyakarta, 28 Oktober 2019.

Sudaryanto, 1993. Metode dan Teknik Analisis Bahasa Pengantar Penelitian Wahana Kebudayaan Secara Linguistis. Yogyakarta: Duta Wacana University Press.

Warto, 2008. "Makna Desain Keris dalam Budaya Jawa" dalam Jurnal Komunika, Vol. 2 No.1 JanuariJuni 2008.

Wahbah, Majdi, 1984. Mu'jamu alMustalahat al-'Arabiyyah Fi alLugah wa al-Adab. Beirut: Maktabah Lubnan.

Wijana, I Dewa Putu, 1996. Dasar-dasar Pragmatik. Yogyakarta: Penerbit Andi.

---------, 2010. Pengantar Semantik Bahasa Indonesia. Yogyakarta: Pustaka

Pelajar.

\section{Sumber dari internet:}

https://www.kediripedia. com/ unescomengakui-keris-sebagai-warisandunia/

http://www.kemenpar.go.id/post/seminarbudaya-keris-sebagai-warisan budaya-tak-benda-indonesia 
(https://sites.google.com/site/thomchrists/ Keris-Jawa-SpiritualKebatinan/Keris-Kamardikan).

https://www.kompasiana. com/meditasi $1582977 \quad$ d26e $7 \mathrm{e}$ 619909c53655/keris-sebagaiwarisan-budaya-dunia-milikindonesia

https://tirto.id/eDRW

https://kbbi.web.id/eksotis

https://republika.co.id/berita/ptmq11458/k eistimewaan-lafaz-allah

https://kaligrafi-islam.blogspot.com/2015/10/kalig rafi-diwani-asal-usul-dansejarah.html

http://arumrum9.blogspot.com/2011/09/se ni-dan-gaya-penulisankaligrafi.html

https://muslim.or.id/29558-konsekuensikalimat-tauhid-laa-ilaaha-illallah. html https://kaligrafi-islam.blogspot.com/search/label /Tughra

https://kbbi.web.id/rajah

https://www.dosenpendidikan.co.id/estetik a-adalah/\#ftoc-heading-10

\section{Nara Sumber:}

1. Bapak Moch Abdillah, kolektor dan pemilik Kios Intan Pusakajaya, pasar Beringharjo.

2. Bapak Mpu Puryadi, Bleberan, Playen, Gunung Kidul

3. Bapak Paino, pemilik keris

4. Bapak Jumani, pemilik keris

5. Ibu Dewi, pemilik keris

6. Bapak Didik, pemilik keris dan ahli mewarangi keris

7. Bapak Verrianto, perajin dan pemilik keris 